\title{
木造軸組構法における柱脚接合部に入力される引張力に関する研究 A STUDY ON TENSION OF COLUMN JOINTS IN WOODEN TRADITIONAL HOUSES
}

\author{
那須秀行*1, 石山央樹*1, 野口弘行*2 \\ Hideyuki NASU, Hiroki ISHIYAMA and Hiroyuki NOGUCHI
}

\begin{abstract}
This monograph relates tension of a column bases in adjustment between an experimental result and calculation by the standard or general design for conventional wooden structure. At first, 2-stories and $126 \mathrm{~m}^{2}$ model house was given static load to examine the experimental measure and then 2 stories and $27 \mathrm{~m}^{2}$ square houses was loaded in the same condition to investigate an effect of perpendicular walls to the load direction. Furthermore, some partial models of columns and sills were experimented to clarify the effect of rocking of column and confining of joint. After the experiments, the experimental measurement was revised with the effect of the rocking and confining, and compared with the standard calculation. As a conclusion, when the story deformation angle is $1 / 50 \mathrm{rad}$. the rocking considerably affects the tension of column bases. The tension is not serious on every column base in the elastic limit. The required value of tension of corner columns seems to be unreasonable, but there is a noteworthy case that the tension more than the required value occurs to the column bases with compressive braces. The perpendicular walls shared with the corner columns seem to carry $1 / 3$ to $1 / 2$ of stress if it has the same specification as the walls in the same direction as the load.
\end{abstract}

\author{
Keywords: Wooden traditional houses, Static test, \\ Tension of joints, Rocking of column, Restriction effect \\ 木造軸組構法 静加力実験 接合部の引張力 柱ロッキング 拘束効果
}

\section{1.はじめに}

2000 年の建設省告示 (1460 号) の中で在来木造住宅における柱脚 接合部の補強方法について仕様或いは設計法が具体的に示された。 一方、1995 年に発生した兵庫県南部地震を受けた当該地震地におい て、当時の基準に則ってはいるがホールダウン金物を用いる等の特 別な補強のない軽微なプレート金物のみで柱脚接合されている木造 住宅であっても無被害のものが多数存在していた。

そこで著者らは、いくつかの実大静加力実験を元にした面材耐力 壁構法と笳かい構法の違い、通し柱構法と管柱構法の違い、直交壁 による効果、幅 $1820 \mathrm{~mm}$ (2P) の単体静加力実験結果の加算則によ る実大建物の挙動予測等一連の研究文献 1,2) を進める中で、柱脚の引 張力についても整理を試みてきた。

本論文は、現在、木造軸組構法の構造設計の拠り所となっている 仕様基準或いは設計法によって生じると想定される柱脚の引張力が、 実際の実験結果とどの程度整合性があるのかを論じている。

具体的には、N 值計算法文献 11) や標準設計法文献 12) で想定される引 張力に対し、実大実験で検出された引張力はどの程度だったのか、 層間変形に伴う柱の傾きによる影響および、耐力面材や筋かい金物 による柱脚の拘束の影響を定量的に把握し、それを反映した真の柱 脚引張力を予測した上で、諸基蕉類との整合性に言及する。

\section{2. 研究の経稦}

まず 2 階建 38 坪プランの実大静加力実験を行い、設計上、柱脚接 合部に想定される引張力と実際に検出された引張力との整合性につ いて研究を始めた（本論 3. .)。

続いて 2 層で 2 間 $\times 2$ 間 $(4 \mathrm{P} \times 4 \mathrm{P})$ の整形プランで同様の実大実 験を行った。その際、加力面とは直交する構面に存在する耐力壁が 建物の変形抑制等に寄与する効果 (以下、直交壁効果) についても 研究を進めた（本論 4.)。これらの研究過程で、

・柱脚に生じる引張力は概わ諸基準類の想定程は大きくないこと

・柱に対するホールダウン金物の取り付く側面の違い（以下、取り 付き勝手）によって、層間変形に伴う柱の傾き（以下、柱のロッ キング）による影響を受け、ホールダウン金物の軸部で検出され る引張力（以下、柱脚の引張力）に違いが生じること

・耐力面材や筋かい金物による柱脚部の拘束効果 (以下、拘束効果) があること、等が明らかになった。

上記を加味し、柱のロッキングの影響や拘束効果を定量的に把握 するため、柱脚部のみ拔粋した部分実験を実施した（本論 5.)。

最後に、先述の実大実験より検出された柱脚の引張力に対して、 部分実験によって明らかとなった柱のロッキングや拘束効果を補正 し、諸基準類で想定される引張力との比較検討を行った(本論 6.)。
*1 住友林業侏 研究員. 工修

*2 明治大学理工学部 教授・工博 


\section{3. 実大実験（実際の住宅プラン）}

実際の設計に基づいたプランにおいて、柱脚接合部に検出される 引張力を検証した。

\section{1 試験体根要（R試倹体）}

試験体は、1 階 $69.6 \mathrm{~m}^{2}$ (約 21 坪)、2 階 $56.3 \mathrm{~m}^{2}$ (約 17 坪)、延べ床 $125.9 \mathrm{~m}^{2}$ (約 38 坪)の面積で、積載荷重（実情を想定し $600 \mathrm{~N} / \mathrm{m}^{2}$ ）を 加えた設計質量は 24.5 ton であった。構造仕様は小幅板斜め貼り合 わせによる壁倍率 2.5 倍の耐力面材を品確法の等級 3 を想定し、建 築基準法施行令 46 条で定められる必要壁量の 1.57 倍で施工したも のである (以下、 $\mathrm{R}$ 試験体)。写真 1 に $\mathrm{R}$ 試験体の全景を、図 1 にプ ランおよび加力方向を示す。

1 階柱脚部のホールダウン金物はN 值計算法文献 11) に従って配置 した。柱脚部の軸力計測はホールダウン金物の軸部に歪みグージを 貼ることで検出し、ナットを所定トルク（スプリングワッシャーが 密着する手締め程度の $3 \mathrm{~N} \cdot \mathrm{m})$ で締め付けた後、水平加力直前にイニ シャライズしその後の増分軸力を測定した。なお、本論で用いたホ ールダウン金物は全て同一仕様で後述の写真 $7 、 8$ の形状と図 12 に示す特性（許容引張耐力 $30 \mathrm{kN}$ ）を有した初期ずれの少ないタイ プであることから、比較的小さな引張力でも検出可能である。

\section{2 実験方法}

試験体は反力床に固定された鉄骨架台にアンカーボルトとホー ルダウン金物で固定した。加力は 1 本の油圧ジャッキを用い層せん 断力分布が $\mathrm{Ai}$ 分布となるように分配冶具を介して 2 階床及び軒桁 位置に行い、水平方向の加力位㯰については 1 階の剛心位置とした。 なお、加力スケジュールは正負交番繰返しによる変位制御とした $( \pm 1 / 600 \rightarrow \pm 1 / 450 \rightarrow \pm 1 / 300$ (3 回) $\rightarrow \pm 1 / 200 \rightarrow \pm 1 / 150$ (3 回) $\rightarrow \pm 1 / 100 \rightarrow \pm 1 / 75$ (3 回) $\rightarrow \pm 1 / 50 \rightarrow$ 最終)。

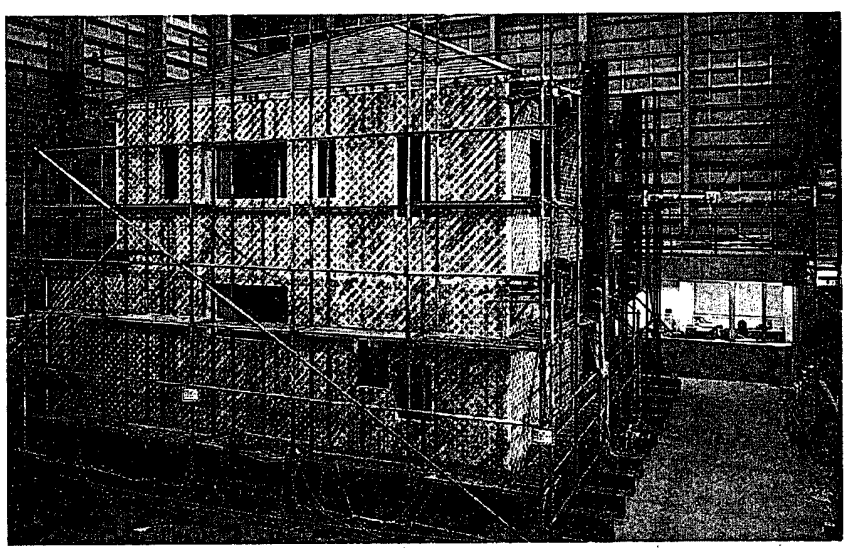

写真 $1 \mathrm{R}$ 試験体 (38 坪プラン) 全景

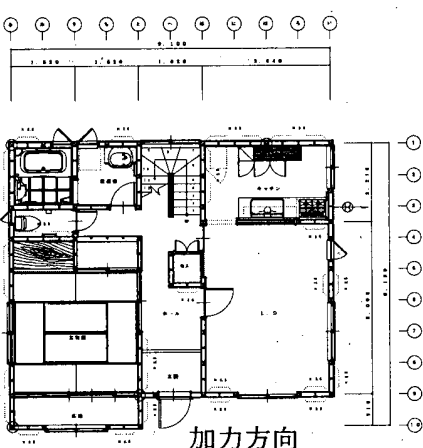

$(-) \stackrel{\text { 加力方向 }}{\longleftrightarrow}(+)$

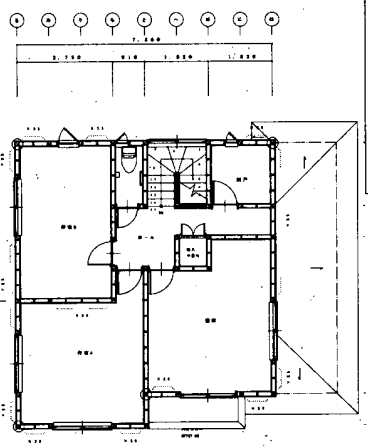

図 1 実大実験（38 坪）プラン

\section{3 建物全体の挙動}

1 層における両端外壁構面の平均層間変形角と水平力（すなわち ジャッキ荷重）の特性を図 2 に示す。地震層せん断力係数 $\mathrm{C}_{0}=0.2$ 相 当の水平力 $(50 \mathrm{kN})$ が加わった時点での層間変形角は $1 / 2700 \mathrm{rad}$. で あった。最大耐力 $\mathrm{P} \max$ は $310 \mathrm{kN}$ を示し、その後ジャッキストロー ク一杯の 1/10rad. まで耐力低下は秪やかであった。

\section{4 柱脚の引張力}

柱の位置によって柱脚の引張力には差があり、図 3 および表 1 に 示す通り、出隅部「る10」で比較的大きな值を示した。しかしなが ら、それでも層間変形角 $1 / 150 \mathrm{rad}$. 時で $7.44 \mathrm{kN} 、 1 / 50 \mathrm{rad}$. 時でも 12.76kNと絶対値としてはそれ程大きな值とはなっていない。

「と10」・「に9」・「い9」は、正側加力において圧縮側の付加軸力 が生じると予測されたが、実際には、1/50rad. 時に6〜10kN程度の引 張力を示した。これはホールダウン金物の取り付き勝手の影響であ り、建物の層間変形に伴う柱のロッキングにより圧縮側の柱であっ てもホールダウン金物には引張力が検出されたためと思われる。

「い5」および「い6」は加力方向とは直交する耐力壁であるが、 負側加力のー1/50 rad. 時には $5 \mathrm{kN}$ 超える引張力が検出された。

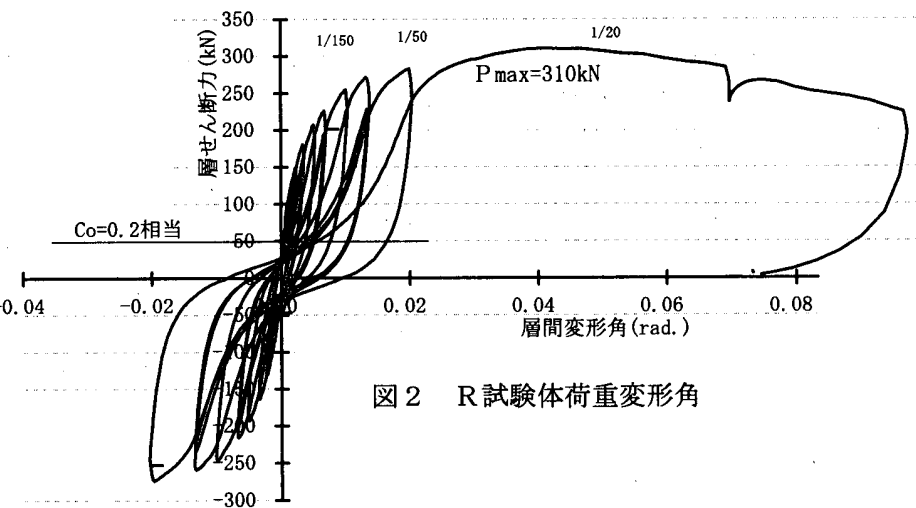

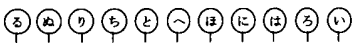

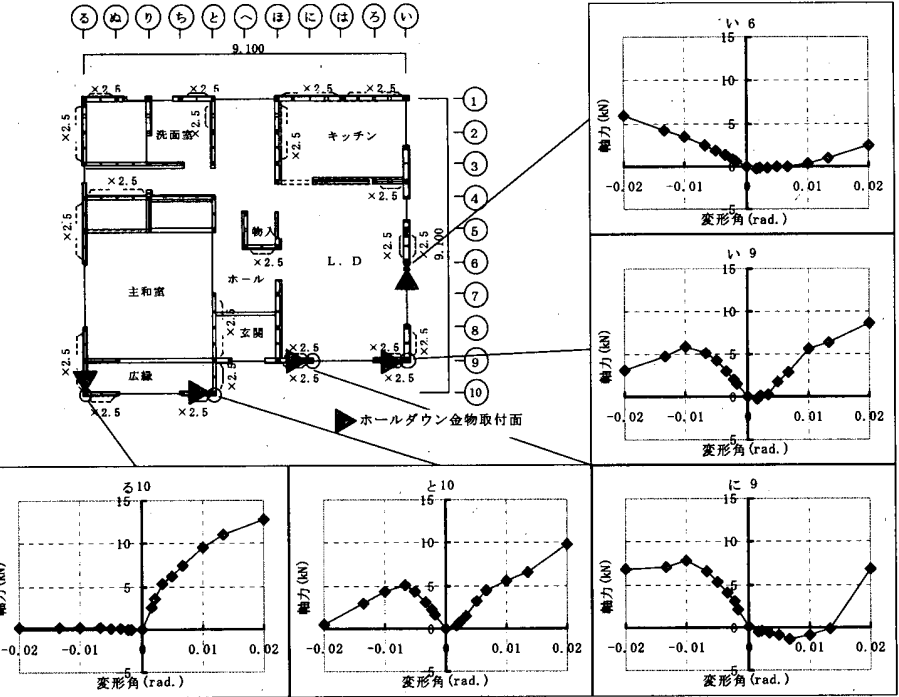

図 $3 \quad \mathrm{R}$ 試験体 1 階柱における層間変形角と柱脚引張力の関倸

表 1 特定変形角毎のホールダウン金物軸力 $(\mathrm{kN})$

\begin{tabular}{c|r|r|r|r|r}
\hline $\begin{array}{c}\text { 層間変形角 } \\
\text { (rad.) }\end{array}$ & \multicolumn{1}{|c|}{ る10 } & \multicolumn{1}{c|}{ と 10} & \multicolumn{1}{c|}{ に 9} & い 9 & い 6 \\
\hline$+1 / 600$ & 2.60 & 0.36 & -0.52 & -0.20 & $(0.64)$ \\
\hline$+1 / 150$ & 7.44 & 4.40 & -1.36 & 2.94 & $(2.48)$ \\
\hline$+1 / 50$ & 12.76 & 9.76 & 6.86 & 8.64 & $(5.92)$ \\
\hline
\end{tabular}




\section{4. 実大実験（整形プラン）}

できる限り本研究とは直接関係のない変動因子を少なくするため、 シンプルかつ偏心のない整形プランにて実大静加力実験を実施した。 柱脚の引張力を検証すると共に、筋かい構法と面材耐力壁構法の違 いおよび直交壁効果についても検証した。

\section{1 試験体概要（SB試験体・S R試験体）}

整形プランは 2 層の 2 間 $\times 2$ 間（各層共 4 坪）の正方形であり、 建物自重と積載荷重 $\left(600 \mathrm{~N} / \mathrm{m}^{2}\right)$ を加えた設計質量は 6.6 ton であっ た。試験体は耐力壁が筋かい仕様（以下、S B 試験体）1 体、面材 仕様（以下、S R 試験体）1 体の計 2 体である。S B 試験体と S R 試験体の全景を写真 2 、写真 3 に示す。

両試験体とも耐力壁の配置は同じであるが、直交壁の配置におい てその対峙する側とは異なる壁配置としている（ジャッキ側は出隅 引張力を比較することで直交壁効果を検討するためである。

S B 試験体と S R 試験体のプラン及び而力壁配置を図 4に示す。 構造仕様を先述の R 試験体と併記して表 2 に示す。

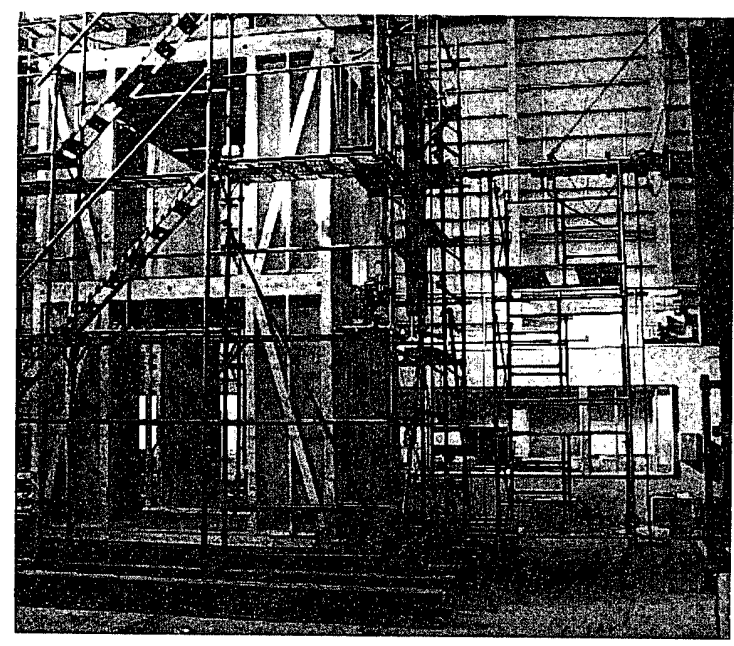

写真 2 S B 試験体全景 部に、その反対側は平部に壁がある)。これは押し側と引き側の柱脚

\section{2 実験方法}

試験体は反力床に固定された鉄骨架台に対し、土台はアンカーボ ルト、耐力壁に取り付く柱はホールダウン金物を用いて固定した。 柱脚の引張力はこのホールダウン金物の軸部に 2 ゲージ 3 線法にて 貼付けられた歪ゲージの值から検出した。

$\mathrm{R}$ 試験体とは異なり、可能な限り余計なパラメータを介入させな いことを意図した S B、S Rの両試験体については、柱の倒れの影 響も極力減じるため、ホールダウン金物は加力方向とは直交側の柱 面に留め付けた (写真 4 )。

加力は $\mathrm{R}$ 試験体同様、 1 本の油圧ジャッキにて $\mathrm{Ai}$ 分布となるよう に分配冶具を用い、 2 階床及び軒桁レベルに変位制御の正負交番各 1 回の繰返しで行った。そのため試験体のジャッキ側とその反対側 の床梁側面に加力プレートを設置し双方のプレートをタイロッドで 結び試験体を挟み込んだ。また、一般的にはジャッキ面に鉄骨の水 平ビームを設置するが、本実験では直交壁の浮き上がり回転等を拘 束しないために当該ビームは用いていない。なお、水平方向の加力 位置については重心位置 (S B、S R 試験体とも剛心と同一) とした。

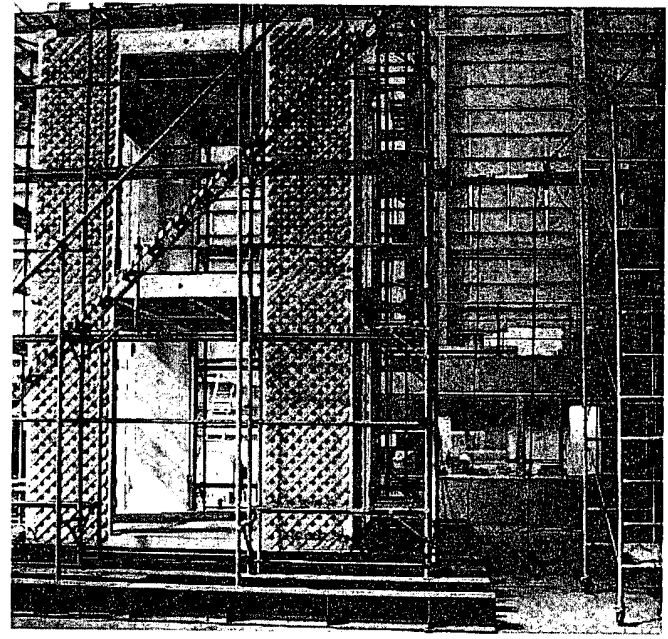

写真 $3 \cdot \mathrm{S} \mathrm{R}$ 試験体全景

表 2 実大実験の試験体概要

\begin{tabular}{|c|c|c|c|c|}
\hline 試験体名（解説） & 大きさ & 質量 $(\mathrm{t})$ & 耐力壁 & 令46条に対する存在壁量比 \\
\hline $\mathrm{R} \quad$ (実設計プラン) & $10 \mathrm{P} \times 9 \mathrm{P}$ & 24.5 & 面材 ※ 1 & 157\%（等級3を満足する壁配置） \\
\hline S B (整形・ブレース) & \multirow{2}{*}{$4 \mathrm{P} \times 4 \mathrm{P}$} & \multirow{2}{*}{6.6} & 筋かい & 110\%（整形プランの四隅に配置） \\
\hline $\mathrm{S} \mathrm{R}$ (整形·面材) & & & 面材※1 & 138\%（整形プランの四隅に配置） \\
\hline
\end{tabular}

床仕様は全て同一で、構造用合板 $24 \mathrm{~mm}$ 厚直貼四周釬打の品確法床倍率3倍仕様 ※ 1 : 小幅板斜め貼り合せ面材（壁倍率2.5倍）

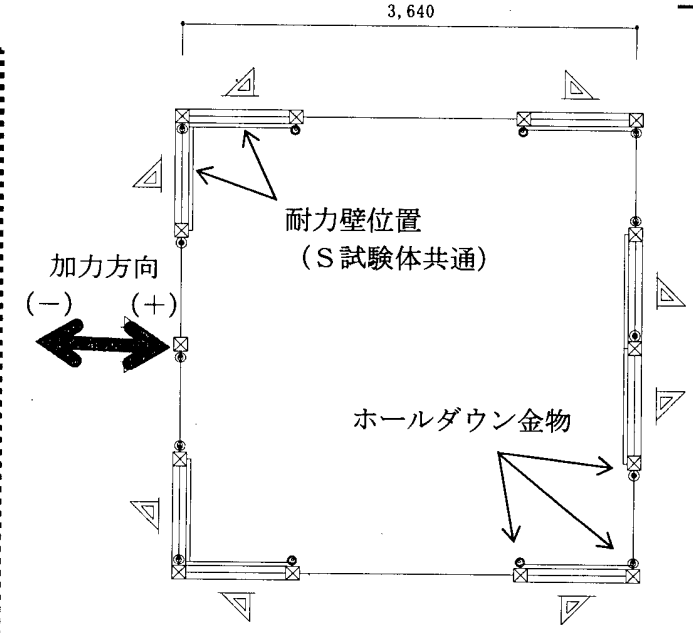

図4 S タイプ試験体プラン・耐力壁配置

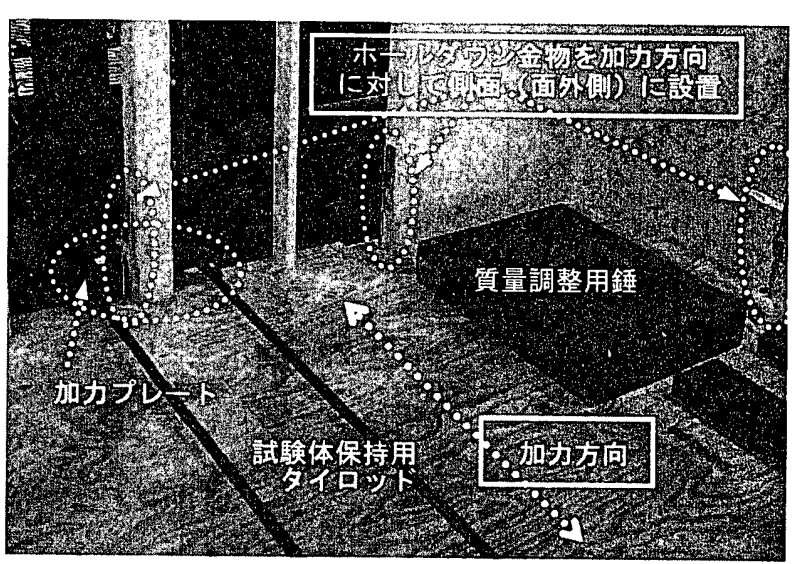

写真 4 試験治具とホールダウン金物の取り付き方向 (2 階床) 


\section{3 実験拮果 - 考察}

\section{3. 1 筋かい搆法と面材構法の量い}

図 5 に示す $\mathrm{P}-\delta$ 特性から読み取ると、耐力壁が面材仕様である $\mathrm{S} \mathrm{R}$ 試験体の方が、筋かい仕様の S B 試験体より層間変形角 1/150rad. 程度まで若干剛性が高かった。

また、1/50rad. 付近で S B 試験体は圧縮筋かいの座屈破壊に伴う 耐力低下を生じたが、S R 試験体ではその後も耐力上昇し $1 / 20 \mathrm{rad}$. 付近で最大耐力となった後、ジャッキストローク一杯の $1 / 10 \mathrm{rad}$. ま で穏やかに耐力低下した。

\section{3. 2 柱㑢の引張力}

図 6 にS B、S R 両試験体の各層間変形角時における個々の柱脚 部における引張力を示す。ただし、ホールダウン金物の構造上、圧 縮力に関しては初期導入軸力分を超えては計測できない。

$\mathrm{C}_{0}=0.2$ 時（層せん断力 $13 \mathrm{kN}$ ）における層間変形角程度では、 $\mathrm{S} \mathrm{B}$ 試験体、S R 試験体とも、小さな值の引張力しか検出されなかった。 S R 試験体は隅部の柱の引張力が大きかったが、S B 試験体では、 圧縮筋かいの突上側の柱脚における引張力が大きかった。

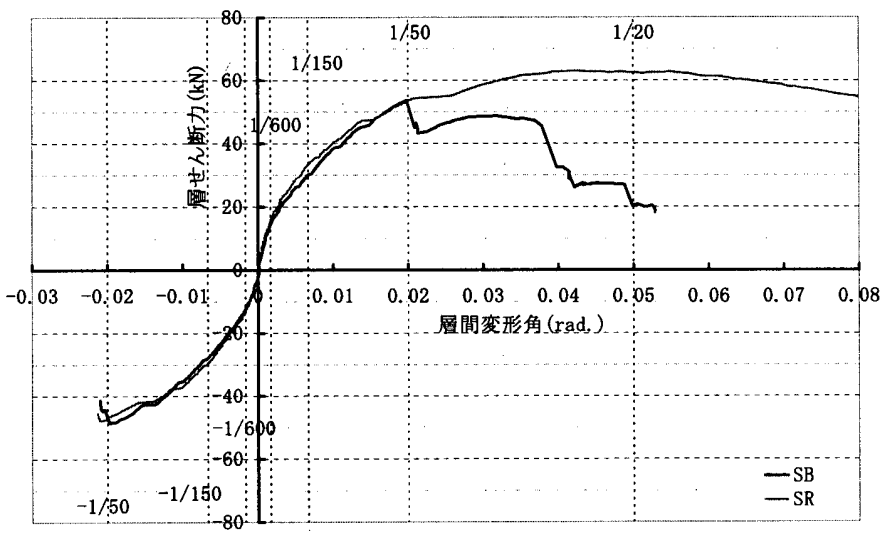

図 $5 \mathrm{~S}$ タイプ試験体の荷重変形角

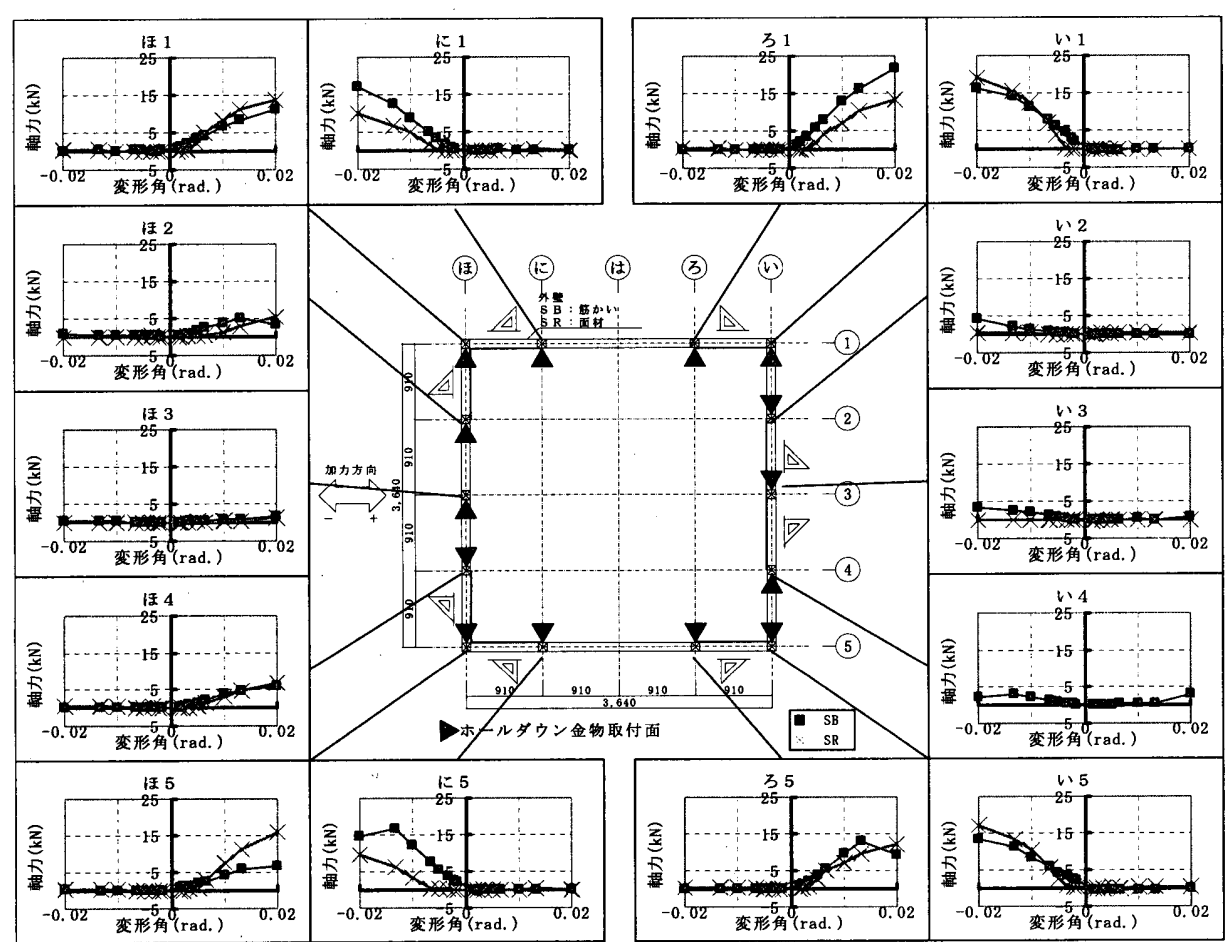

図 6 S B、S R 試験体における層間変形角と柱脚の引張力

\section{3. 3 直交壁効果}

図 6 に示寸ように、「ほ」通りでは試験体の出隅に耐力壁が存在し、 「1」或いは「5」通り構面から見れば直交壁が隣接していること になる。逆に、「い」通りでは出隅から $1 \mathrm{P}$ 離れたところに耐力壁が あり、直交壁は隣接していない。

図 7 に加力方向から見れば直交構面である「ほ」および「い通り の特定層間変形角時における柱脚の引張力を示す。隣接直交壁なし の「い」通りと比較すると、隣接直交壁有りの「ほ」通りのほうが 隅部の「1」および「5」通りで柱脚の引張力が小さく、逆にその 隣の「2」および「4」通りはいい通りより引張力が大きい傾向 が看取され、こちらに力が流れていることが解る。

本実験のように隣接する直交壁が同一仕様であれば、隣り合う各 柱脚部の引張力をどうし比較することで、各耐力壁に分配されてい るせん断応力の割合も予測可能と考えられる。図 7 の「ほ」通りの 1/50rad. 時を例にとれば、実験值のため多少のばらつきはあるもの の、概ね 1/2〜1/3 程度の応力が隣接直交壁に流れていると考えて大 過ないと思われる。

図 5 からも直交壁の効果は確認できる。正側加力の場合は「ほ」 通りに引張力がかかり、当該「ほ」通りには隣接直交壁がある。逆 に、負側加力の場合は「い」通りに引張力がかかる。つまり、図 5 における第 1 象限が隣接直交壁有り、第 3 象限が隣接直交壁なしの 荷重変形角関係となる。同じ変形角時どうしの耐力を比較すると第 1 象限の方が絶対值として若干高い值を示しており、その差分は直 交壁による効果と考えられる。

なお、直交壁効果に関しては、床剛性によりその影響度は変化す ると考えられるが、本論では表 2 に示すとおり全て寒情に合わせた 同一仕様にて実験を行っている。

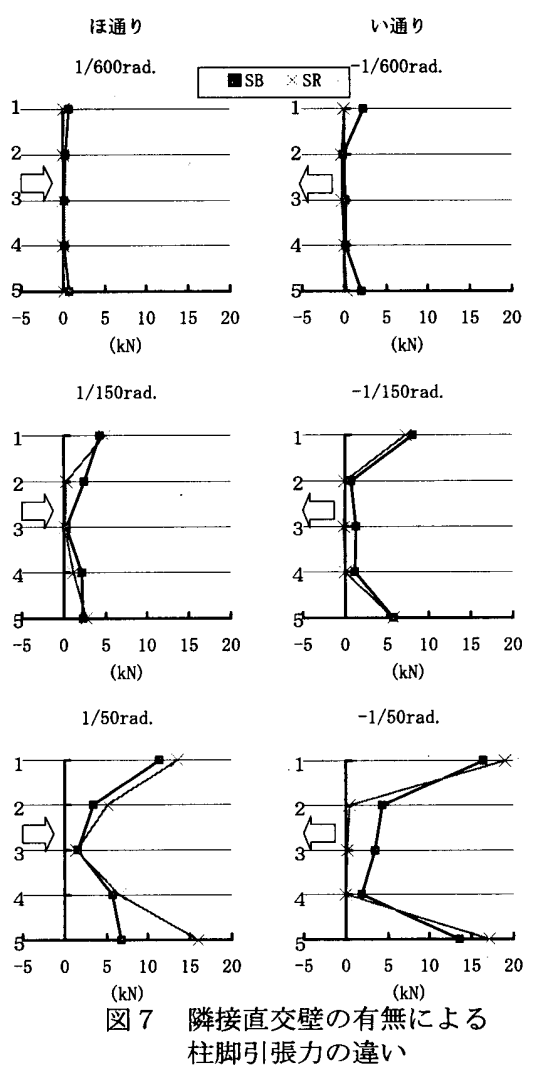




\section{5. 部分実験（柱脚部のみを抜拚）}

3.のR試験体および4．のS B 試験体および S R 試験体で実施 した実大実験において測定された引張力は、柱の傾きによるホール ダウン金物の取り付き勝手の影響や、耐力面材或いは筋かい金物に よる拘束効果の影響を含んでいる。その影響を取り除き、真の柱脚 引張力と考えられる值を定量的に把握するため、柱脚部のみを抜き 出し部分実験を行った。

\section{1 実倹概要}

部分実験の試験体概要を表 3 に、試験体図を図 8、試験状況を写 真 5 に示寸。試験体は大別して柱のロッキング関連で 2 タイプ（ホ ールダウン金物の取付き面が加力面か(1)、直交面か(2)(3)(4)）あり、 面材等による拘束効果関連で 3 タイプ（接合具がホールダウン金物 か(5)、面材か(6)(7)(8)、筋かい金物か(9) ある。柱のロッキングの影 響を見る場合、ホールダウン金物の柱への取り付き面を変えて柱に 強制的に傾きを与え、その時の軸力を計測した。面材等の拘束効果 については、3 種類の接合具別に単純引張剛性を計測した。

表 3 部分試験体概要

\begin{tabular}{|c|c|c|c|}
\hline 試験タイプ & 試験体名 & 接合具 & 取付き状況 \\
\hline \multirow{4}{*}{$\begin{array}{l}\text { 柱ロッキリグ } \\
\text { (水平加力) }\end{array}$} & (1)X-HD-P-10 (6 体) & \multirow{4}{*}{ ホールダ的金物 } & 加力面 1 本 (初期軸力 $10 \mathrm{kN}$ ) \\
\hline & (2) $\mathrm{X}-\mathrm{HD}-\mathrm{C}-10$ (2 体) & & 直交面 2 本 ( " \\
\hline & (3) $\mathrm{X}-\mathrm{HD}-\mathrm{C}-05$ (2 体) & & 直交面 2 本 (" 各 $05 \mathrm{kN})$ \\
\hline & (4) $\mathrm{X}-\mathrm{HD}-\mathrm{C}-01$ (2 体) & & 直交面 2 本 (" \\
\hline \multirow{5}{*}{$\begin{array}{l}\text { 拘束効果 } \\
\text { 単純引張 } \\
\text { (鉛直加力) }\end{array}$} & (5) $\mathrm{Y}-\mathrm{HD}-01$ (3 体) & ホールダウン金物 & 1 本 (初期軸力 $01 \mathrm{kN}$ ) \\
\hline & (6) $\mathrm{Y}-\mathrm{KD}-03$ (3 体) & \multirow{3}{*}{$\begin{array}{c}\text { 面材耐力壁 } \\
\text { 倍率 } 2.5 \text { 倍仕様 }\end{array}$} & 仕様 1 (N50 釘 3 本) \\
\hline & (7)Y-KD-05(3 体) & & $" \prime 2(" \prime 5$ 本 $)$ \\
\hline & (8)Y-KD-07 (3 体) & & $" 3(" 7$ 本 $)$ \\
\hline & (9) $\mathrm{Y}-\mathrm{BP}$ (3 体) & 筋かい金物 & D マーク金物 BP2 同等ビスタタイフ \\
\hline
\end{tabular}

柱のロッキングの影響を検証（(1)〜(4)）拘束効果を検証（(5)〜(9)

(1)

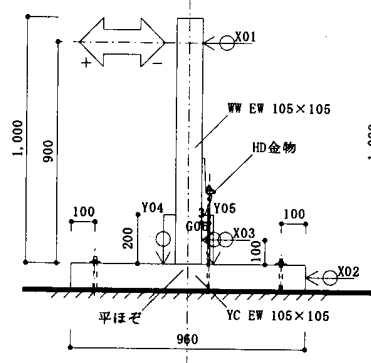

(2)(3)(4)

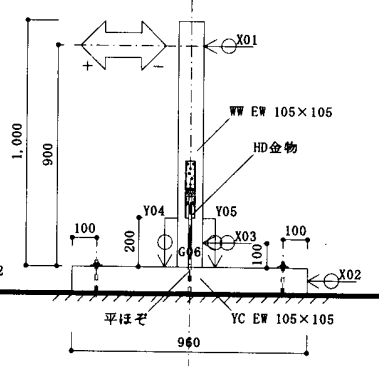

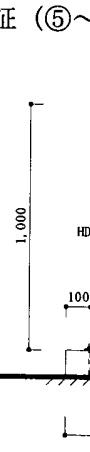

\section{2 実酫方法}

各試験体は土台をアンカーボルトにて架台に止め付け、ホールダ ウン金物は直接鉄骨架台から引っ張った。加力は 1 本の油圧ジャッ キを用い、水平もしくは鉛直方向に加力した。

柱のロッキングの影響を検証する水平加力試験体（11) (4)）は、 変位制御の正負交番各 1 回繰返しで行った。ただし、部分実験装置 の関係上、実大実験であれば自ずと存在する柱の鉛直荷重分（圧縮 軸力分）は、ホールダウン金物を所定トルクで締め付けた引張力に より、表 3 に示す「初期軸力」として与えた。一方、拘束効果をみ る鉛直加力の試験体については単調引張りとした。

\section{3 実験結果・考察}

\section{3. 1 柱のロッキング時における中立軸の位置}

ロッキングによる各試験体の柱脚の浮き上がり状態を図 9 に示す。 中立軸は、取り付くホールダウン金物の軸材の近辺に発生し、その 傾向は初期軸力が大きい程顕著であることが解った。
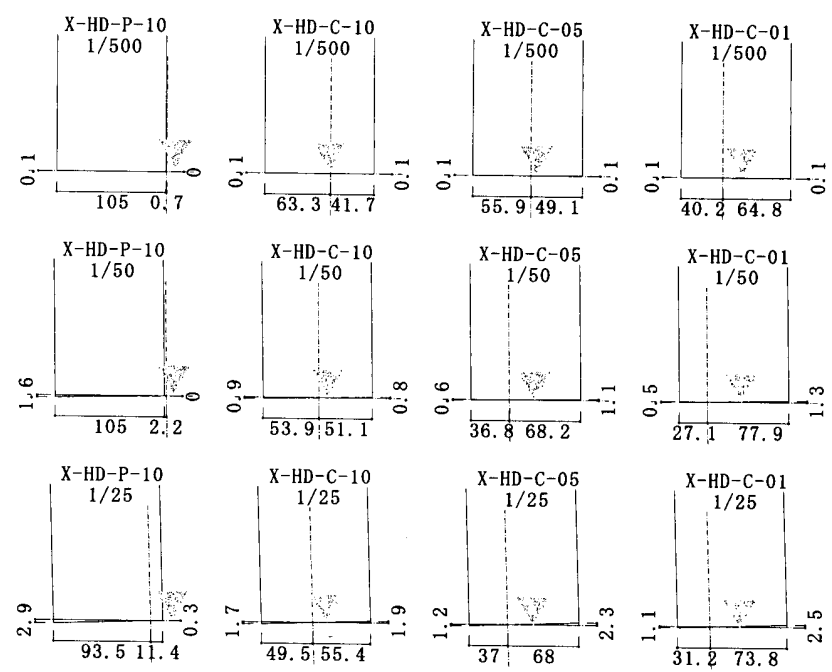

図 9 柱脚部の浮き上がり状況

図 8 部分実験試験体図
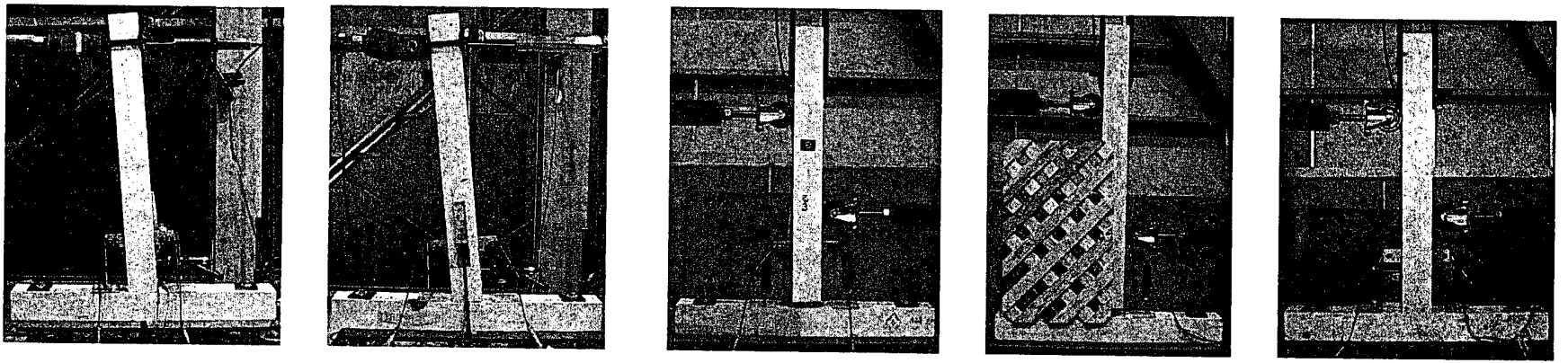

写真 5 部分実験試験体加力状況 


\section{3.2 柱のロッキングによる軸力変動}

\section{1） ホールダウン金物が加力面に取付く場合（試験体(1)}

図 10 および写真 6 に示すとおり、試験体(1)X-HD-P-10のように加 力面にホールダウン金物が取り付く場合、柱のロッキングによって 生じる付加軸力は、層間変形角 $1 / 500 \mathrm{rad}$. で1〜2kN程度と影響は少な かったが、1/50rad. では平均 $12 \mathrm{kN}$ 程度と無視できない影響があった。 なお、本論において層間変形角 $1 / 500 \mathrm{rad}$. に着目したのは、著者ら の過去の実験結果より損傷限界程度としての目安としたものであり 同様に1/50rad.については安全限界程度の目安としたためである。

\section{2） ホールダウン金物が加力方向と側面の場合（試験体(2)(3)(4)}

加力方向に対して側面にホールダウン金物が取り付く場合（写真 7 )、図 11 に示すとおり、層間変形角 $1 / 500 \mathrm{rad}$. では初期軸力に関 わらずいずれも殆ど影響なかった。ただし、1/50 rad. では試験体(2) (初期軸力 $10 \mathrm{kN}$ ) で約 $0 \sim 1 \mathrm{kN} 、$ 試験体(3) (初期軸力 $5 \mathrm{kN}$ ) で約 $2 \sim 4 \mathrm{kN} 、$ 試験体(4)（初期軸力 $1 \mathrm{kN}$ ) で約 $3 \sim 4.5 \mathrm{kN}$ と若干影響があった。

\section{3. 3 拘束效果}

\section{1）面材㓦力壁による拘束効果（試験体(5)6(7)(8)}

まず、試験体(5)より基準とするホールダウン金物の特性（図１２） と破壊性状（写真 8）を得た。次に、試験体(6)(7)8ににより面材によ る拘束効果が及ぶ範囲も検証すべく、面材の長さを変えて実験を実 施した。面材の面内回転剛性に違いはあるものの、いずれも最終的 には土台と面材との接合釘の抜け出しが支配的であった（写真 9 ）。

図 12 に示すホールダウン金物の特性と図 13 に示す面材による 拘束力の同一変位どうしを比較すると、変位 $1.8 \mathrm{~mm}$ 時（層間変形角 1/500rad. 相当)での拘束効果はホールダウン金物の 1 1.5 割程度、 変位 $18.2 \mathrm{~mm}$ 時 (50rad. 相当)では 1 割程度と確認された。

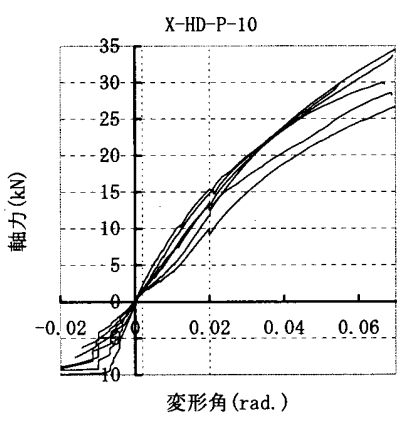

図10 ロッキング加力面(1)

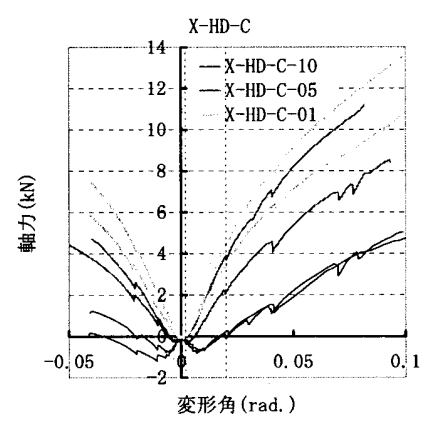

図 11 ロッキング直交面(2)(3)(4)

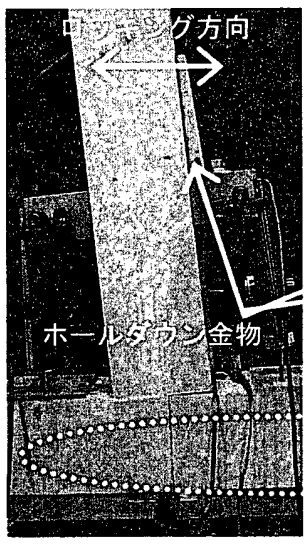

写真 6 柱ロッキング 加力面に取付 (1)

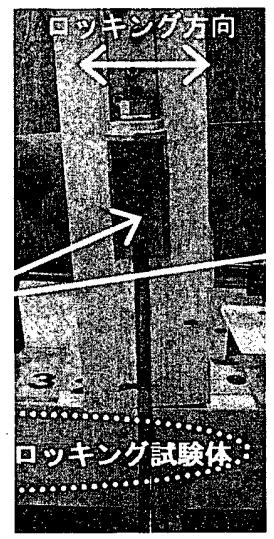

写真 7 柱ロッキング 側面に取付 (2)(3)(4)

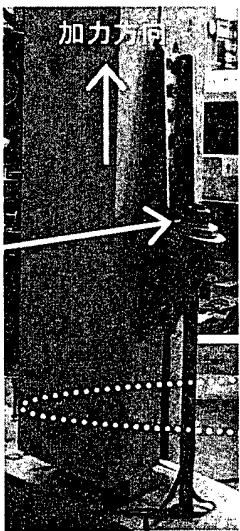

写真 8 拘束効果 ホールダウン (5)

\section{2）筋かい金物による拘束効果（試験体(9)}

図 13 に示すとおり、筋かい金物による柱と土台との拘束効果に つては、 $9 \mathrm{~mm}$ 程度の変位すなわち $1 / 100 \mathrm{rad}$. 相当までは面材による拘 束効果の 2 倍程度の拘束力を筋かい金物が有していることが解った。

その後、筋かい金物は写真 10 に示すような変形に向けて拘束力 は減少し、安全限界程度（18.2mm 変位 $1 / 50 \mathrm{rad}$. 相当）では面材と概 ね同程度の拘束力となることが確認された。なお、本実験に使用し た筋かい金物は D マーク金物 BP2 と同等評価されたものである。

\section{4 部分実験の結果}

\section{1）柱のロッキングによる影䈏}

建物の層間変形に伴い柱がロッキングすることによるホールダウ ン金物に入力される引張力の影響については、層間変形角 1/500 rad. 程度では殆ど無視できる。

しかしながら、1/50rad. 程度においては、ホールダウン金物が柱 の加力面であれ側面であれ、いずれの場合でも軸力変動は小さくな い。特に実験等で精密さを要する場合には、ホールダウンの取り付 き勝手に留意する必要がある。

\section{2) 拘束効果}

面材耐力壁や筋かい金物による土台と柱脚の拘束効果については、 絶対值としてはそれ程大きくないが、層間変形角の初期段階から安 全限界と考えられるような大弯形時まで、安定的な拘束効果がある ことが解った。

而力面材や釘のせん断或いは筋かいによる引張力との複合応力と なるため単純な加算とはならないが、今後、これら拘束効果の相応 分は、柱脚の固定金物充当分として算入可能な合理設計も視野に入 れて良いのではないかと思われる。

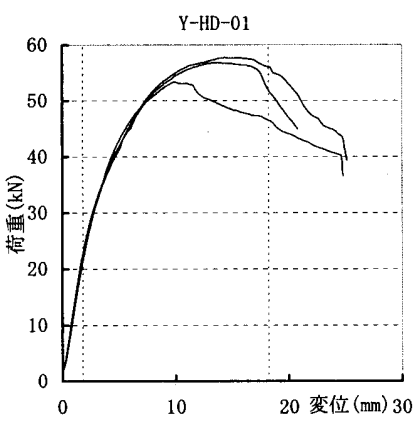

図 12 ホールダウン (5)

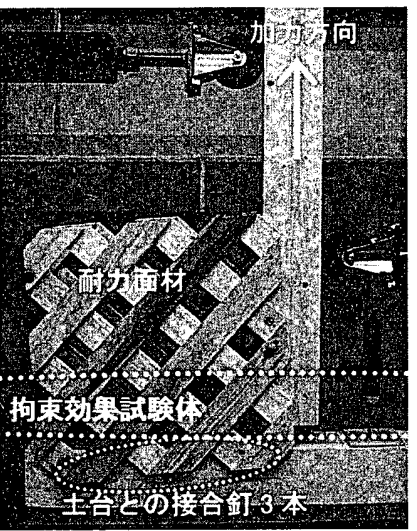

写真 9 拘束効果 耐力面材 (6)(7)

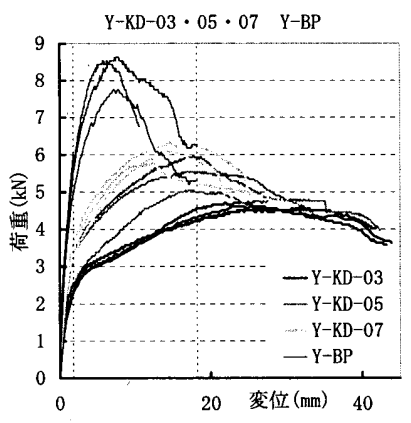

図 13 拘束効果 (6)(7)(8)

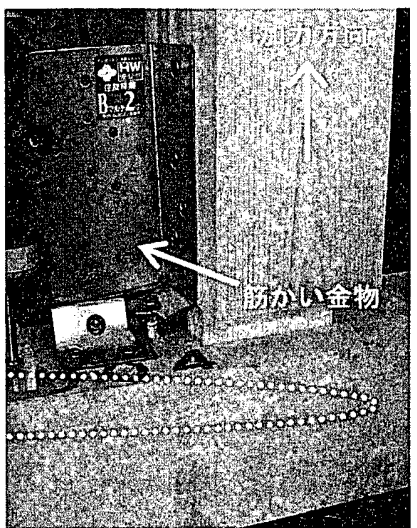

写真 10 拘束効果 筋か心金物 (9) 


\section{6. 実験と設計との整合性}

まず、実大実験で検出された柱脚の引張力に対し部分実験結果を 反映させ、真の柱脚引張力と考えられる值を算出する。具体的には、 柱の傾きによるホールダウン金物の取り付き勝手の影響や拘束効果 といった影響を取り除く。

その上で、この真の柱脚引張力と諸基準・設計法で想定されてい る引張力との比較検討を行う。

\section{1 部分実䀫結果の単純化と実大実験への補正条件}

補正を行うに当たり各部分実験結果の值を同じ試験体仕様毎に平 均値化した。柱のロッキング効果を特定変形角時の軸力の平均値と して図 14 に示す。同様に拘束効果についても、特定変位時の引張 力（圧縮力）の平均值として図 15 に示す。

表 4 に各仕様毎の柱脚の引張強度、剛性およびホールダウン金物 に対する剛性比を示す。引張剛性は $1.8 \mathrm{~mm}$ 変位時（1/500 rad. 相当） および、 $18.2 \mathrm{~mm}$ (1/50 rad. 相当) 変位時の各々の割線剛性とした。

各実大実験に対して補正適用する值とその適用条件を表 5 に示す。

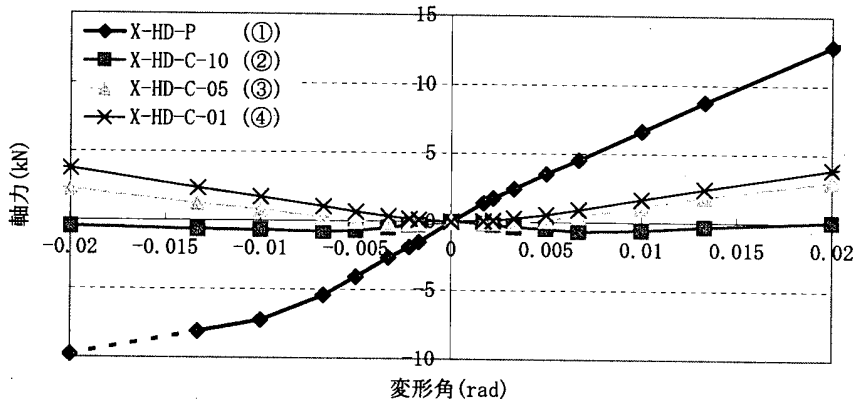

図 14 特定変形角時ロッキング効果

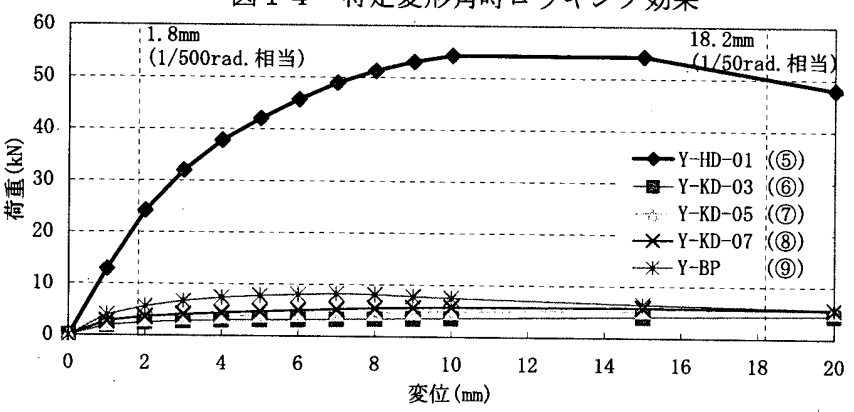

図 15 特定変位時拘束効果

表 4 面材・竻かい金物の拘束効果剛性

\begin{tabular}{|c|c|c|c|c|c|}
\hline & 強度 & $\begin{array}{c}\text { 剛性 } \\
1.8 \mathrm{~mm} \text { 時 }\end{array}$ & 剛性比 & $\begin{array}{c}\text { 剛性 } \\
18.2 \mathrm{~mm} \text { 時 } \\
\end{array}$ & 剛性比 \\
\hline Y-HD-01 (5) & 56.00 & $\begin{array}{l}12.29 \\
\end{array}$ & $100.0 \%$ & 2.83 & 100.0 \\
\hline $\mathrm{Y}-\mathrm{KD}-$ & 4.63 & 1.36 & $11.1 \%$ & 0.24 & $8.5 \%$ \\
\hline $\mathrm{Y}-\mathrm{KD}$ & 5.5 & 1.68 & $13.7 \%$ & 0.30 & $10.7 \%$ \\
\hline $\mathrm{Y}-\mathrm{KD}-07(8))$ & 6.06 & 1.96 & $15.9 \%$ & 0.31 & 11.1 \\
\hline $\begin{array}{ll}\text { Y-BP } & \text { (9) } \\
\end{array}$ & 8.14 & 3.06 & $24.9 \%$ & 0.32 & 1.1 .29 \\
\hline
\end{tabular}

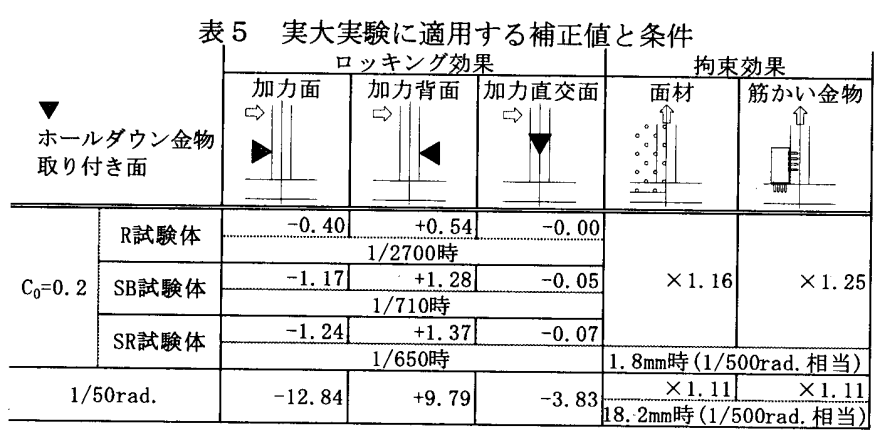

\section{2 補正手法}

6. 2. 1 ロッキング奻果を補正

実大実験において測定されたホールダウン金物の引張軸力は、耐 力壁の転倒モーメントにより発生する引張力と前述の柱ロッキング 効果との複合力であると考えられる。即ち、測定值からロッキング 効果の影響分を差し引いた值が耐力壁による実際の引張力であると 考えられる。

測定された軸力、耐力壁による引張力、ロッキング効果による引

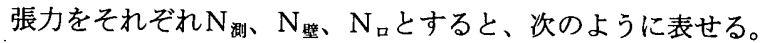

$\mathrm{N}_{\text {壁 }}=\mathrm{N}_{\text {测 }}-\mathrm{N}_{\text {口 }} \cdots A$ A式

\section{2.2 拘束効果を補正}

一方、測定された軸力は、耐力壁による引張力から耐力面材や筋 かい金物による拘束効果を差し引いた值であると考えられる。即ち、 測定值に拘束効果の影響分を付加した值が実際の耐力壁による引張 カであると思われる。

測定された軸力、耐力壁による引張力を $\mathrm{N}_{\text {测、 }} \mathrm{N}_{\text {壁、ホールダウン }}$ 金物に対する拘束効果の剛性比を $\mathrm{k}$ とすると、次のように表せる。

$\mathrm{N}_{\text {壁 }}=\mathrm{N}_{\text {测 }}+\mathrm{k} \cdot \mathrm{N}_{\text {测 }} \cdots$ B式

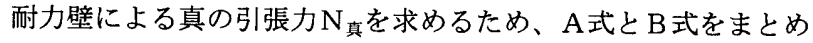

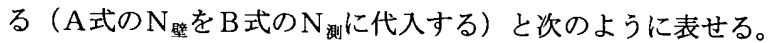

$\mathrm{N}_{\text {真 }}=(1+\mathrm{k}) \cdot\left(\mathrm{N}_{\text {测 }}-\mathrm{N}_{\text {口 }}\right) \cdots \mathrm{C}$ 式

最終的に、C式によって柱のロッキングおよび拘束効果の両影響 は補正可能と考えられる。

\section{3 㭪正結果および考察}

図 16 に $\mathrm{C}_{0}=0.2$ 時および $1 / 50 \mathrm{rad}$. 時における実験值と $\mathrm{A}$ 式、C式 による補正後の想定值比の変化を示す。また、この手法を用いて最 終的に真の柱脚引張力と思われる結果をN值計算法による想定值と 比較しながら表 6 に示す。なお、剛性比 $\mathrm{k}$ の值は変形角によって暫 時変化すると考えられるが、ここでは簡略化するため部分実験にお ける $1.8 \mathrm{~mm}$ 変位時および、18. $2 \mathrm{~mm}$ 変位時をそれぞれ $\mathrm{C}_{0}=0.2$ 時、1/50 rad. 時として適用し剛性比配分した。
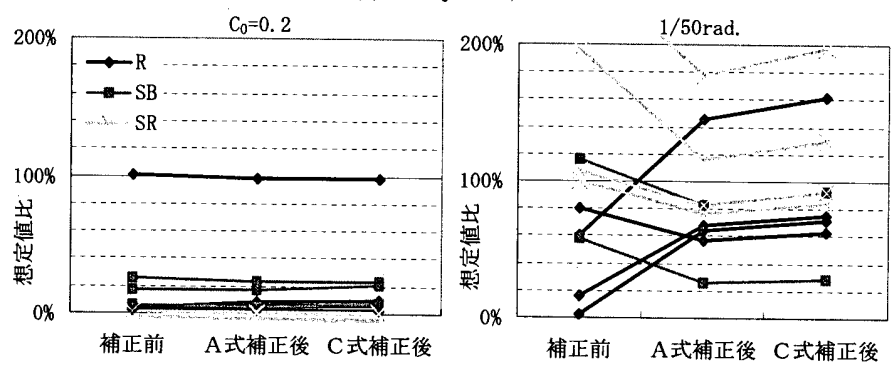

図 16 補正前後における想定値の変動

表 6 想定値と実験補正值（ロッキングと拘束効果を補正：C式）

\begin{tabular}{|c|c|c|c|c|c|c|c|}
\hline 試験体 & 測定 & $\begin{array}{l}\text { 加力 } \\
\text { 方向 } \\
\end{array}$ & $\begin{array}{c}\text { 想定値 } \\
\text { (N值計算) }\end{array}$ & \multicolumn{2}{|c|}{$\begin{array}{l}\text { 測定值 }(\mathrm{kN}) \\
\mathrm{C}_{0}=0.2\end{array}$} & \multicolumn{2}{|c|}{$\begin{array}{r}\text { (想定値比) } \\
1 / 50 \mathrm{rad} .\end{array}$} \\
\hline \multirow{4}{*}{$\mathrm{R}$} & る10 & 押側 & 15.90 & $0 . \overline{42}$ & $(2.6 \%)$ & 9.92 & (62.4 \\
\hline & $\varepsilon 10$ & 引側 & 15.90 & 1.04 & $(6.5 \%)$ & 11.40 & (71. 7 \\
\hline & に9 & 引側 & 11.40 & 1.14 & $(10.0 \%)$ & 18.49 & $(162.2$ \\
\hline & W9 & 引側 & 19.08 & 1.09 & $(5.7 \%)$ & 14.31 & \\
\hline \multirow{4}{*}{ SB } & ほ5 & 押側 & 11.66 & 0.80 & $(6.9 \%)$ & 3.28 & $(28.1)$ \\
\hline & に5 & 引側 & 2. 12 & 2.07 & $(97.7 \%)$ & 10.71 & \\
\hline & 35 & 押側 & 2.12 & 0.49 & $(23.1 \%)$ & 5.18 & (244. \\
\hline & W5 & 引側 & 11.66 & 2.50 & $(21.5 \%)$ & 10.75 & \\
\hline \multirow{4}{*}{$\mathrm{K}$} & ほ5 & 押側 & 15.90 & 0.08 & $(0.5 \%)$ & 13.43 & $(84.5$ \\
\hline & に5 & 引側 & 4.77 & -0.21 & $(-4.5 \%)$ & 6.17 & $(129.3$ \\
\hline & 35 & 押側 & 4.77 & -0.19 & $(-4.1 \%)$ & 9.39 & $(196.9$ \\
\hline & W5 & 引側 & 15.90 & 0.26 & $(1.6 \%)$ & 14.70 & \\
\hline
\end{tabular}




\section{3. 1 ロッキングおよび拘束効果の影踣}

図 16 および表 6 に示すとおり、 $\mathrm{C}_{0}=0.2$ 時の引張力は殆どの箇所 で絶対值として小さく補正前後の変化も小さい。しかしながら、 1/50rad. 時ではロッキングの影響が大きいといえる。また、A式補 正後とC式補正後ではそれ程大きな変化がない(図 16 ) ことから、 拘束効果はそれ程大きくないといえる。

\section{3. 2 想定值と真の柱脚引張力との整合性}

真の柱脚引張力と考えられる表 6 の結果を図 17 、図 18 にグラ フ化した。その際、正負加力それぞれにN值計算法文解11) および標準 計算法文藃12) よる想定値を併記した。更に図 17 には建物の質量から 求まる $\mathrm{C}_{0}=0.2$ 時と共に存在壁量から求まる弾性限界時（耐力壁量の 余裕分だけ大きな外力がかかった状態）も記した。N值計算法と標 準計算法とで想定される值が異なるのは、当該階より上階の鉛直力 による抑え込み効果が反映されているためであり、特に本論のS タ イプ試験体のように柱本数に対し床面積が小さい場合、想定值は $\mathrm{N}$ 值計算法より標準計算法の方が大きくなる。

図 17 に示すとおり、 $\mathrm{C}_{0}=0.2$ 時および弹性限界時においていずれ の柱脚にも絶対值として大きな引張力は発生していない。

図 18 に示すとおり、1/50rad. 時では接合金物の安全率 (Pmax/Py) が通常1.5倍以上ある事を勘案し、想定值も1.5倍してい る。 3 試験体の正負加力とも想定值が真の柱脚引張力をほぼ回っ ており、特に隅柱における想定值は過大と思われる。ただし、圧縮 筋かいの突上げ側となる柱脚部においては、絶対值そのものはそれ 程大きくはないものの、元々の想定值が小さいためそれを超える引 張力がかかる場合があることが解った。

\section{7. まとめ}

・柱のロッキングおよび耐力面材や筋かい金物による拘束効果を定 量的に把握し、真の柱脚引張力を求める手法を提案した。

・層間変形角 $1 / 50 \mathrm{rad}$. 時において柱のロッキングの影響が大きい。 ・3体の実大実験によれば、 $\mathrm{C}_{0}=0.2$ 時および弾性限界時においていず れの柱脚も絶対值としてさほど大きな引張力は発生しなかった。 ・隅柱の想定值はやや過大と思われるが、圧縮筋かいの突上げ側の 脚部では想定值以上の引張力がかかる場合があり注意を要する。 ・同仕様の隣接直交壁には $1 / 2 \sim 1 / 3$ 程度の応力が流れると思われる。

参考文献

1) 那須秀行,町田健一,塩沢伸明, 石山央樹, 大橋好光 : 面材耐力壁を用いた木 造軸組構法住宅の実大静加力実験 (その1）～実験概要および筋交い構法と の比較〜

日本建築学会大会学術講演梗概集 (北陸), C-1, pp. 109-110,2002.8

2) 塩沢伸明, 那須秀行, 町田健一, 石山央樹, 大橋好光：面材耐力壁を用いた木 造軸組構法住宅の実大静加力実験 (その2) 〜壁の加算則の検証〜, 日本建 築学会大会学術講演梗概集 (北陸)， C-1,pp. 111-112,2002.8

3 ）石山央樹, 那須秀行, 町田健一, 塩沢伸明, 大橋好光 : 面材耐力壁を用いた木 造軸組構法住宅の実大静加力実験 (その3) 〜柱頭柱脚金物に入力される引 張力〜，日本建築学会大会学術講演梗概集 (北陸)，C-1, pp. 113-114, 2002.8

4) 那須秀行, 石山央樹, 塩沢伸明, 野口弘行: 木造軸組工法における構造仕様の 違いについて(その1）～通し柱と管柱、面材耐力壁と筋かい耐力壁の構造 性能比較〜,

日本建築学会大会学術講演梗概集 (東海)，C-1, pp. 355-356, 2003.9

5 ) 石山央樹,那須秀行, 塩沢伸明, 野口弘行 : 木造軸組工法における構造仕様の 違いについて(その2) 〜柱頭柱脚に入力される引張力〜, 日本建築学会大 会学術講演梗概集 (東海), C-1, pp. 357-358, 2003.9

6) 竹村雅行, 稲山正弘, 村上雅英 : 在来軸組工法木造住宅の構造設計手法の開 発(その66) 〜平面保持仮定にもとづく柱脚柱頭接合部軸力の一般解〜, 日本建築学会大会学術講演梗概集 (東海), C-1, pp. 285-286, 2003.9
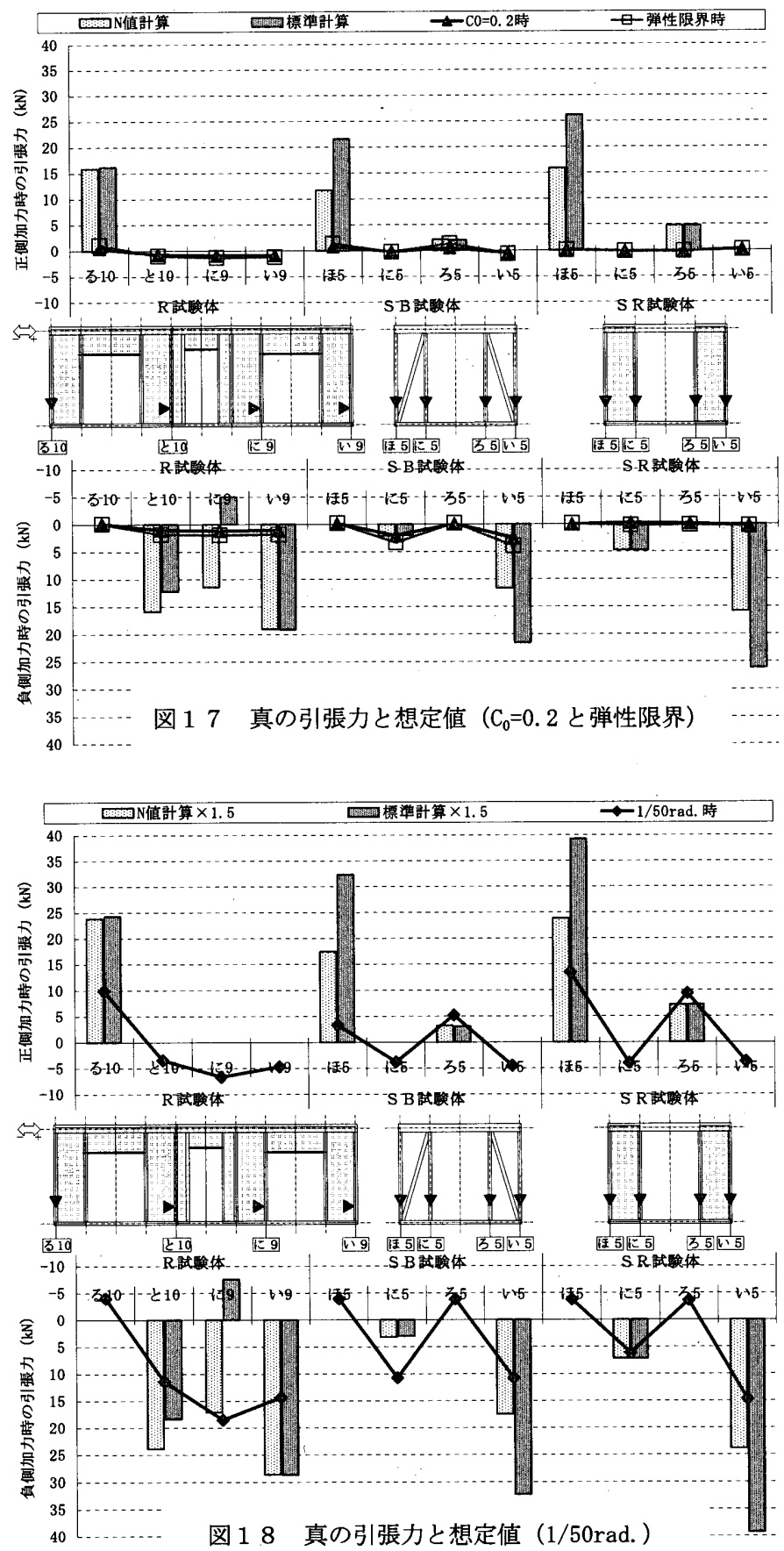

7 ) 稲山正弘, 村上雅英, 那須秀行, 石山央樹 : 在来軸組工法木造住宅の構造設計 手法の開発 (その67) 柱脚柱頭接合部軸力一般解の立体建物への適用方 法と検証～，日本建築学会大会学術講演梗概集 (東海), C-1, pp. 287-288, 2003. 9

8) 佐藤俊平, 稲山正弘, 村上雅英, 那須秀行, 石山央樹 : 在来軸組工法木造住宅 の構造設計手法の開発(その68) 〜下屋付 2 階建の柱脚柱頭接合部軸力の 計算、および実大実験との比較〜，日本建築学会大会学術講演梗概集 (東 海), C-1, pp. 289-290, 2003. 9

9 ）腰原幹雄, 阿川将樹, 大橋好光, 宮澤健二, 坂本功 : 偏心を有する木質面材耐 力壁構造の静的挙動に関する実験的研究, 日本建築学会構造系論文集 No. 558 pp. $165,2002.8$

10）冨崎修平,稲山正弘,村上雅英 : 在来軸組構法による面材有開口壁の柱頭柱 脚の必要接合耐力算定法の提案，日本建築学会構造系論文集 No. 563 pp. $123,2003.1$

11）国土交通省住宅局建築指導課他：建築物の構造関係技術基準解説書，工学 図書, 2001.3

12）日本住宅・木材技術センター: 木造軸組工法住宅の許容応力度設計(第3版), 2004.4

13）建築技術：建築技術, pp. 148-164, 2001.6

14）エクスナレッジ：建築知識, pp. 177-178, 2004.8 